International

Journal of Th $_{\text {hysical }}$

DOI : 10.15740/HAS/IJPE/8.1/14-19

e ISSN-0976-7924 Visit us : www.researchjournal.co.in

Research Paper

Volume 8 | Issue 1 | April, 2015 | 14-19

\title{
Effect of physical training and yogic practices, on selected physiological variables and motor ability components among college men students
}

K. BALASUBRAMANIAN, S. KANNADASAN ${ }^{1}$ AND C. SENTHIL KUMAR ${ }^{1}$

Received : 11.05.2014; Revised : 22.02.2015; Accepted : 06.03.2015

Members of the Research Forum

Associated Authors:

'Department of Physical Education

and Health Sciences, Alagappa

University, KARAIKUDI (T.N.) INDIA

Author for correspondence :

K. BALASUBRAMANIAN Department of Physical Education and Health Sciences, Alagappa University, KARAIKUDI (T.N.) INDIA

\section{-ABSTRACT}

Yoga plays an important role by brining the therapeutic effect in Asthmas, diabetes, hypertension and respiratory troubles. Some yoga has both preventive as well as curative values. Positive charges in the life style of the people can brought through yoga. During the period of education, Yoga can make them aware of their bodies and further make them realize the need of emotional and physical well being. The present study has been mainly designed to find out the effect of selected yogic practices and physical training on motor ability and physiological variables of college men. To accomplish the purpose of this study, the experimental design, the subjects, the criterion variables and test of measuring them and their variables and methods to applying them have been systematically presented. Thirty subjects were selected at random from the Alagappa Arts College in Karaikudi. For the study, the average age of the subject was 18 to 21 years; the selected students were further divided at random into three group's namely yogic practices, Physical training and control groups. All the subjects were normal and healthy male students, the sample was considered as the true representative of population. The number of each group was ten.

- KEY WORDS : Flexibility, Agility, Resting Pulse rate, Breath holding time

- HOW TO CITE THIS PAPER : Balasubramanian, K., Kannadasan, S. and Kumar, C. Senthil (2015). Effect of physical training and yogic practices, on selected physiological variables and motor ability components among college men students. Internat. J. Phy. Edu., 8 (1) : 14-19. 